\title{
The Impact of Polyamine Precursors, Polyamines, and Steroid Hormones on Temporal Messenger RNA Abundance in Bovine Satellite Cells Induced to Differentiate
}

\author{
Caleb C. Reichhardt ${ }^{1}{ }^{\circledR}$, Lillian L. Okamoto ${ }^{1}$, Laura A. Motsinger ${ }^{1}{ }^{(D}$, Brian P. Griffin ${ }^{1}$, Gordon K. Murdoch ${ }^{2,3}$ \\ and Kara J. Thornton ${ }^{1, *}$ \\ 1 Department of Animal, Dairy and Veterinary Science, Utah State University, 4815 Old Main Hill, \\ Logan, UT 84322, USA; ccreichhardt@gmail.com (C.C.R.); lelehua521@gmail.com (L.L.O.); \\ laura_smith95@live.com (L.A.M.); brian.griffin0710@gmail.com (B.P.G.) \\ 2 Department of Animal, Veterinary and Food Sciences, University of Idaho, Logan, ID 83844, USA; \\ gordon.murdoch@wsu.edu \\ 3 Department of Animal Sciences, Washington State University, Pullman, WA 99163, USA \\ * Correspondence: kara.thornton@usu.edu; Tel.: +1-435-797-7696
}

Citation: Reichhardt, C.C.; Okamoto L.L.; Motsinger, L.A.; Griffin, B.P.; Murdoch, G.K.; Thornton, K.J. The Impact of Polyamine Precursors, Polyamines, and Steroid Hormones on Temporal Messenger RNA Abundance in Bovine Satellite Cells Induced to Differentiate. Animals 2021, 11, 764. https://doi.org/ 10.3390/ani11030764

Received: 3 February 2021

Accepted: 8 March 2021

Published: 10 March 2021

Publisher's Note: MDPI stays neutral with regard to jurisdictional claims in published maps and institutional affiliations.

Copyright: (c) 2021 by the authors. Licensee MDPI, Basel, Switzerland. This article is an open access article distributed under the terms and conditions of the Creative Commons Attribution (CC BY) license (https:/ / creativecommons.org/licenses/by/ $4.0 /)$.
Simple Summary: In the U.S., approximately $90 \%$ of all cattle on feed receive an anabolic implant at some point during production. Despite the widespread use, how they operate to increase growth of cattle remains unknown. Polyamines are amino acid derivatives, which are potent growth stimulants, produced through the polyamine biosynthetic pathway. Emerging research suggests that the hormones in anabolic implants interact with the polyamine biosynthetic pathway. The purpose of this research was to investigate the effects of steroidal hormones, polyamine precursors, and polyamines on mRNA abundance of bovine satellite cells, muscle precursor cells. The results from this study suggest that polyamine precursors and polyamines alter transcription factors involved in induction of differentiation of bovine satellite cells and the polyamine biosynthetic pathway, while the hormones in anabolic implants alter genes involved in the polyamine biosynthetic pathway. These results mean that polyamines may impact differentiation of bovine satellite cells, ultimately affecting growth of cattle.

Abstract: Emerging research suggests that hormones found in anabolic implants interact with polyamine biosynthesis. The objective of this study was to determine the effects of steroidal hormones, polyamines and polyamine precursors on bovine satellite cell (BSC) differentiation and polyamine biosynthesis temporally. Primary BSCs were induced to differentiate in $3 \%$ horse serum (CON) and treated with $10 \mathrm{nM}$ trenbolone acetate (TBA), $10 \mathrm{nM}$ estradiol (E2), $10 \mathrm{nM}$ TBA and $10 \mathrm{nM} \mathrm{E2,}$ $10 \mathrm{mM}$ methionine, $8 \mathrm{mM}$ ornithine, $2 \mathrm{mM}$ putrescine, $1.5 \mathrm{mM}$ spermidine, or $0.5 \mathrm{mM}$ spermine. Total mRNA was isolated $0,2,4,8,12,24$, and $48 \mathrm{~h}$ post-treatment. Abundance of mRNA for genes associated with induction of BSC differentiation: paired box transcription factor 7 , myogenic factor 5 , and myogenic differentiation factor 1 and genes in the polyamine biosynthesis pathway: ornithine decarboxylase and S-adenosylmethionine-were analyzed. Overall, steroidal hormones did not impact $(p>0.05)$ mRNA abundance of genes involved in BSC differentiation, but did alter $(p=0.04)$ abundance of genes involved in polyamine biosynthesis. Polyamine precursors influenced $(p<0.05)$ mRNA of genes involved in BSC differentiation. These results indicate that polyamine precursors and polyamines impact BSC differentiation and abundance of mRNA involved in polyamine biosynthesis, while steroidal hormones altered the mRNA involved in polyamine biosynthesis.

Keywords: anabolic implants; bovine satellite cells; beef; polyamines; skeletal muscle

\section{Introduction}

For the livestock industry, skeletal muscle growth is extremely important as, through a series of changes, it becomes meat [1,2]. There is a positive correlation between environmen- 
tal sustainability and improved productivity [3]. Therefore, understanding mechanisms that improve skeletal muscle growth is necessary to produce cattle that are more environmentally sustainable, while decreasing costs to producers. Mammalian muscle fiber number is primarily fixed at birth, making hypertrophy of existing fibers the primary mechanism for postnatal growth [4-6]. However, hypertrophy eventually requires additional nuclei from satellite cells for muscle growth [4-7]. Satellite cells are muscle precursor cells that proliferate, then differentiate and fuse into myotubes or with existing muscle fibers to support hypertrophy [5]. Differentiation and phenotypic maturation are necessary for satellite cells to fuse [8]. Markers of differentiation in skeletal muscle include increased expression of myogenic differentiation factor $1(M y o D)$, myogenic factor 5 (Myf5), and myogenin, and decreased expression of paired box transcription factor 7 (Pax 7$)[6,9,10]$.

Anabolic implants are typically composed of estradiol (E2) and/or other compounds such as trenbolone acetate (TBA) and are used to increase the overall efficiency of beef cattle production $[7,11,12]$. As such, approximately $90 \%$ of cattle on feed in the U.S. receive an anabolic implant some point during production [13]. While proven effective, the physiological mechanisms by which TBA and E2 function to increase growth in cattle are not fully understood [14-21]. Treatment of bovine satellite cells (BSCs) with TBA or E2 results in increased proliferation and protein synthesis rates [14-21]. Previous research investigating the effects of steroidal hormones on BSCs has established that both E2 and TBA increase fusion rates at both 48 and $72 \mathrm{~h}$ post-treatment [22]. However, knowledge gaps regarding anabolic implants and growth of skeletal muscle still remain.

Emerging research has demonstrated that TBA and E2 may interact with the polyamine biosynthetic pathway [23-25]. Polyamines, including putrescine (PUT), spermidine (SPD), and spermine (SPE), are important for normal cell growth and differentiation [26-31]. Polyamines are orally active, and found in relatively high concentrations in common feedstuffs, such as silage [29]. Research shows that when BSCs are treated with polyamines or polyamine precursors, proliferation rates increase [25]. The major substrates used in the polyamine biosynthesis pathway to produce PUT, SPD, and SPE are methionine (MET), ornithine (ORN), and arginine [32]. The production of PUT from ORN, catalyzed by ornithine decarboxylase (ODC), is the first rate-limiting step in the polyamine biosynthesis pathway [33]. The second rate-limiting step is the production of decarboxylatedS-adenosylmethionine, catalyzed by S-adenosylmethionine decarboxylase (AMD1) [33]. In proliferating BSCs, TBA has been shown to interact with the polyamine biosynthesis pathway [25].

The interactions of steroidal hormones, polyamine precursors, polyamines, and the polyamine biosynthetic pathway have not been well characterized in differentiating BSCs. Therefore, the objective of this research was to investigate whether steroidal hormones (TBA and E2), polyamines (PUT, SPD and SPE), and polyamine precursors (MET and ORN) influence mRNA abundance of BSCs induced to differentiate and the polyamine biosynthesis pathway temporally.

\section{Materials and Methods}

\subsection{Bovine Satellite Cell Isolation}

Bovine satellite cells were isolated from three different steers raised and harvested following procedures approved by the Institutional Animal Care and Use Committee (IACUC Protocol \# 10216) at Utah State University. These steers were approximately one year of age and weighed approximately $315 \mathrm{~kg}$ at harvest and had not previously received any anabolic implants or other growth promotants. Animals were euthanized by captive bolt, followed by exsanguination. Bovine satellite cell isolation was performed as previously described $[15,16,18,34,35]$. In brief, using sterile techniques, one $\mathrm{kg}$ of the semimembranosus was collected and transported approximately $12 \mathrm{~km}$ to the laboratory. Approximately $45 \mathrm{~m}$ elapsed from exsanguination to the start of BSC isolation. The following was conducted using aseptic techniques in a tissue culture hood. Adipose and connective tissue were removed, and the muscle was passed through a sterile meat grinder. 
The ground muscle was then incubated with a $0.1 \%$ pronase in Earl's Balanced Salt Solution for $1 \mathrm{~h}$ at $37{ }^{\circ} \mathrm{C}$ and mixed every $10 \mathrm{~min}$. The mixture was then centrifuged at $1500 \times g$ for $4 \mathrm{~min}$ at $4{ }^{\circ} \mathrm{C}$ and the resultant pellets were resuspended in phosphate-buffered saline solution (PBS: $140 \mathrm{mM} \mathrm{NaCl}, 1.0 \mathrm{mM} \mathrm{KH}_{2} \mathrm{PO}_{4}, 3.0 \mathrm{mM} \mathrm{KCl}$, and $8.0 \mathrm{MM} \mathrm{Na}_{2} \mathrm{HPO}_{4}$ ) and centrifuged again at $500 \times g$ for $10 \mathrm{~min}$. The recovered supernatant was centrifuged at $1500 \times g$ for $10 \mathrm{~min}$ to pellet the mononucleated cells. The PBS wash and centrifugation were repeated two more times. The monocucleated cell preparation was suspended in $4{ }^{\circ} \mathrm{C}$ Dulbecco's Modified Eagle Medium (DMEM), containing 10\% fetal bovine serum (FBS), and $10 \%$ dimethylsulfoxide (DMSO), and then frozen at $-80{ }^{\circ} \mathrm{C}$. The cells were stored in liquid nitrogen until subsequent use. Clonal analysis of satellite cell cultures established from these preparations showed that between $80 \%$ and $90 \%$ of the cells in these preparations were myogenic. Phenol red was not present in any of the culture media used in this study, as phenol red is known to interact with the androgen and estrogen receptors.

\subsection{Bovine Satellite Cell Culture}

Bovine satellite cells were plated as previously described [16]. In brief, BSC cultures were plated in $4 \mathrm{~cm}^{2}$ wells that were precoated with reduced growth factor basement membrane Matrigel (Corning, Tewksbury, MA, USA) diluted 1:50 (v/v). Cultures were plated at a density of $2 \mathrm{~g} / \mathrm{cm}^{2}$, which produced cultures that were approximately $70 \%$ confluent after $72 \mathrm{~h}$ in culture. Cells were plated in Dulbecco's Modified Eagle Medium (DMEM) containing $10 \%$ FBS and incubated at $37{ }^{\circ} \mathrm{C}$ with $5 \% \mathrm{CO}_{2}$ in a water saturated environment [16]. At $72 \mathrm{~h}$, cultures were rinsed twice with DMEM and fresh media with 10\% FBS was added to cultures. Cultured cells from each of the three animals used in the study were completed in duplicate, providing a total of six samples per time point per treatment.

\subsection{Induction of Differentiation and Treatment of BSC Cultures}

Bovine satellite cell cultures were grown until a confluency of approximately $80 \%$ was reached, at which point the cells were induced to differentiate in DMEM containing $3 \%$ horse serum and $1.5 \%$ bovine serum albumin-linoleic acid (BSA-LA) following previous described methods [17], and containing the treatments. Treatments were added to differentiation media and consisted of a control (CON), steroidal hormones (10 nM TBA, 10 nM E2 or $10 \mathrm{nM}$ TBA and $10 \mathrm{nM}$ E2), polyamines (2 mM PUT, $0.5 \mathrm{mM} \mathrm{SPE}$, or $1.5 \mathrm{mM} \mathrm{SPD}$ ) or polyamine precursors ( $8 \mathrm{mM}$ ORN or $10 \mathrm{mM}$ MET). The treatment concentrations were chosen based on previous research examining polyamine levels in bovine lymphocytes [27], as no research has been completed in bovine skeletal muscle cells, and experiments previously conducted by our lab group demonstrating that these concentrations increase BSC proliferation [25].

\subsection{RNA Isolation, Quantification, and cDNA Synthesis}

Total RNA was extracted from BSC cultures using the Absolutely RNA Microprep Kit (Agilent Technologies, Cedar Creek, TX, USA) as per the manufacturer's protocol. Cells were lysed at $0,2,4,8,12,24$, and 48 h post-treatment. In brief, lysis buffer was added directly to the culture dish and a cell scraper was used to further lyse the cells. The cell lysate was then vortexed and an equal volume of $70 \%$ ethanol was added. The mixture was then centrifuged and filtered. A series of wash buffers were added and then the RNA was eluted and stored at $-80{ }^{\circ} \mathrm{C}$. Isolated RNA was quantified using a BioTek all-in-one microplate reader using Gen5 2.0 software (BioTek Instruments, Winooski, VT, USA), and quality was determined using the 260/280 ratio. Samples with a ratio greater than 2.0 were deemed high enough quality for cDNA synthesis. All RNA samples were treated with deoxyribonuclease (Ambion, Foster City, CA, USA) before beginning cDNA synthesis using a high-capacity cDNA reverse transcription kit (Applied Biosystems, Foster City, CA, USA) following the manufacturer's protocol. 


\subsection{Quantitative Real-Time PCR}

Real-time PCR quantification of mRNA was assessed using the Taqman MGB primer/ probe system. Primer express 3.0 software (Applied Biosystems, Foster City, CA, USA) was used to design the primers and probes for all genes. A list of primers can be found in Table 1. An ABI 7500 real-time PCR system (Applied Biosystems, Foster City, CA, USA) was used to detect relative mRNA abundance of Ribosomal 18S (18S), ODC, AMD1, PAX7, MYF5, or MYOD. All samples were analyzed in duplicate. If the $\mathrm{Ct}$ of the duplicates differed by more than 0.5 , the sample was reanalyzed. Ribosomal $18 \mathrm{~S}$ was used as the housekeeping gene using the per sample $\Delta C_{t}$ method [36-38]. Ribosomal $18 \mathrm{~S}$ has been found to be within the range of acceptance for stability in bovine muscle tissue [38] and is commonly used as a housekeeping gene in experiments analyzing cultured skeletal muscle cells $[39,40]$.

Table 1. Primer and Probe Sequences used in Real-Time PCR.

\begin{tabular}{|c|c|c|}
\hline Abbreviation & GBA $^{1}$ Number & Primers and Probe Sequences, $5^{\prime}-3^{\prime}$ \\
\hline $18 S^{2}$ & AF243428 & $\begin{array}{l}\text { FP: CCACGCGAGATTGAGCAAT } \\
\text { RP: GCAGCCCCGGACATCTAA } \\
\text { TP: ACAGGTCTGTGATGCC }\end{array}$ \\
\hline$P A X 7^{3}$ & XM_616352.4 & $\begin{array}{c}\text { FP: AGGACGGCGAGAAGAAAGC } \\
\text { RP: CCCTTTGTCGCCCAGGAT } \\
\text { TP: AAGCACAGCATCGAC }\end{array}$ \\
\hline MYF5 4 & NM_174116.1 & $\begin{array}{c}\text { FP: AGCCCCACCTCAAGTTGCT } \\
\text { RP: GCTGTCAAAACTGCTGCTCTTTC } \\
\text { TP: CATGCCTGAATGTAAC }\end{array}$ \\
\hline$M Y O D^{5}$ & NM_001040478.2 & $\begin{array}{l}\text { FP: CCGCCTGAGCAAAGTCAAC } \\
\text { RP: GGGCAGCCGCTGGTTT } \\
\text { TP: TGCACGTCTAGCAACC }\end{array}$ \\
\hline$M_{Y O G} 6$ & XM_001790098.1 & $\begin{array}{l}\text { FP: CCGCCACGCTGAGAGAGA } \\
\text { RP: GGCCTCGAAGGCTTCATTC } \\
\text { TP: GGCCTCGAAGGCTTCATTC }\end{array}$ \\
\hline$O D C^{7}$ & NM_174130 & $\begin{array}{l}\text { FP: CTGTACTGATCCTGAGACCTTTG } \\
\text { RP: GCTTTACATCCTCTGATCCAGG } \\
\text { TP: ATCTCTGATGCCCGCTGTGTCTTT }\end{array}$ \\
\hline$A M D 1^{8}$ & NM_173990 & $\begin{array}{l}\text { FP: TGCTGGAGGTTTGGTTCTC } \\
\text { RP: TCAAAAGTATGTCCCACTCGG } \\
\text { TP: TTGGTTTGCGTCGGGTTGCTG }\end{array}$ \\
\hline
\end{tabular}

Forward primer (FP), reverse primer (RP) and TaqMan ${ }^{\circledR}$ probe (TP) sequence along with gene bank accession (GBA) number for the genes analyzed by employing TaqMan ${ }^{\circledR}$ primer probe system of real-time PCR. ${ }^{1}$ GenBack Accession Number ${ }^{2}$ Ribosomal $18 S .{ }^{3}$ Paired box transcription factor 7. ${ }^{4}$ Myogenic factor 5. ${ }^{5}$ Myogenic differentiation factor $1 .{ }^{6}$ Myogenin. ${ }^{7}$ Ornithine decarboxylase. ${ }^{8} \mathrm{~S}-$ adenosylmethionine decarboxylase.

\subsection{Statistical Analysis}

Statistical analysis was performed using the MIXED procedure of SAS (version 9.4; SAS Inst. Inc., Cary, NC, USA). All data are presented as the least square mean \pm standard error of the mean (SEM). Data from multiple assays performed on cells isolated from different animals were combined. Preliminary analyses indicated that there were no effects $(p>0.05)$ observed for either the assay number or the different animals, and as such, these two factors were included as random variables in the model. Three separate analyses were completed to determine the effects of steroid hormones, polyamines, and polyamine precursors over time. As samples were analyzed over time, a repeated-measures analysis was performed to assess the fixed effects of treatment (steroidal hormone, polyamine or polyamine precursor), time, and treatment ${ }^{*}$ time. When treatment differences were found to be significant $(p<0.05)$, contrasts were constructed to determine whether each of the nine different treatments were different from the control cultures. Relative mRNA abundance of 
the CON cultures over time can be found in Figure 1. Tukey-Kramer adjustments were made in both the repeated-measures analysis, as well as in the contrast statements to control for multiple comparisons. This analysis was performed for data obtained from quantitative real-time PCR. Gene expression analysis using TAQman quantitative real-time PCR was performed by analyzing the relative expression of each sample calculated as 2-relative threshold cycle $(\Delta \mathrm{Ct})$.

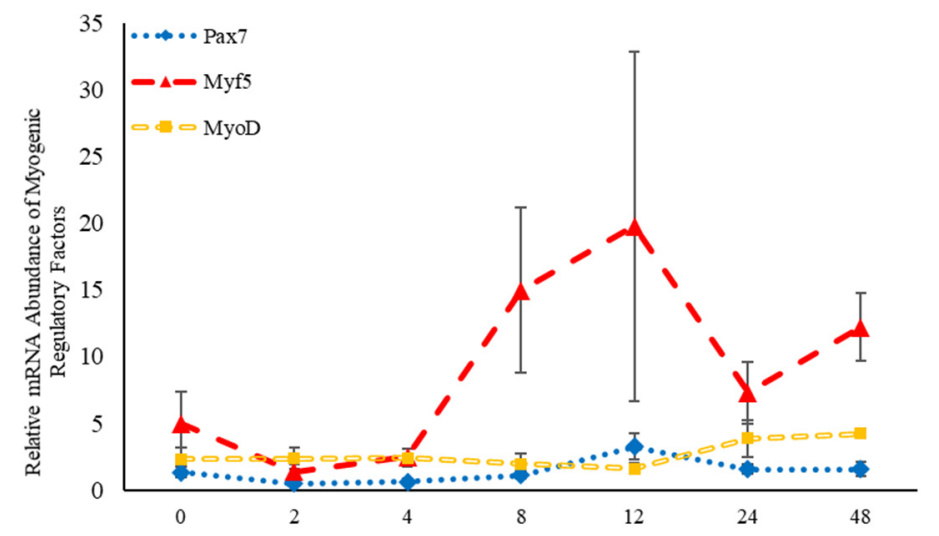

(A)

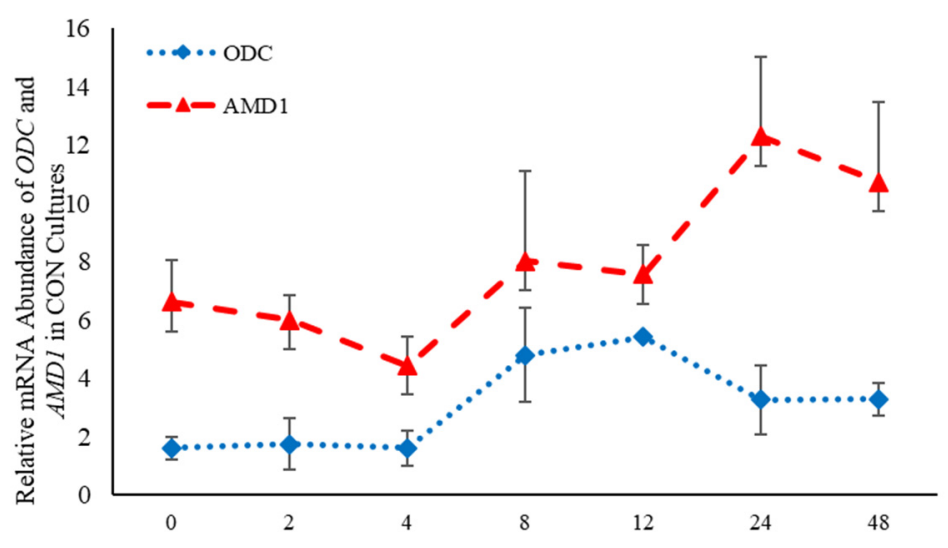

(B)

Figure 1. Relative mRNA abundance of the myogenic regulatory factors (A): paired box transcription factor 7 (Pax7), myogenic factor 5 (Myf5), and myogenic differentiation factor $1(M y o D)$ and relative mRNA abundance of the two rate limiting steps involved in the polyamine biosynthesis pathway (B): S-adenosylmethionine decarboxylase (AMD1) and ornithine decarboxylase (ODC) from controltreated primary bovine satellite cells cultures over time. Abundance was measured 0, 2, 4, 8, 12, 24 and $48 \mathrm{~h}$ after treatment, as described in the Materials and Methods.

\section{Results}

\subsection{The Effects of Steroidal Hormones on Abundance of mRNA Involved in BSC Differentiation}

No effects $(p>0.05)$ of steroidal hormone or steroidal hormone time were observed relative to abundance of $P A X 7, M Y F 5$, or MYOD mRNA at 2, 4, 8, 12, 24, or 48 h posttreatment (Figure 2). However, treatment with E2 increased abundance of PAX7 mRNA at both $2(p=0.02)$ and $8 \mathrm{~h}(p=0.04)$ when compared to control cultures (Figure $2 \mathrm{~A})$. Trenbolone acetate increased ( $p=0.001)$ mRNA abundance of MYF5 $4 \mathrm{~h}$ post-induction to differentiate and decreased $(p=0.04)$ MYF5 abundance at $12 \mathrm{~h}$ post-induction to differentiate compared to control cultures (Figure 2B). Additionally, both E2 $(p=0.02)$ and ETBA $(p=0.03)$ increased abundance of MYOD mRNA $8 \mathrm{~h}$ post-induction to differentiate 
(Figure 1A). Abundance of MYF5 and MYOD mRNA was affected $(p<0.05)$ by time (Figure 2). Abundance of MYF5 increased $(p=0.02)$ for the first $8 \mathrm{~h}$ of induction to differentiate and then decreased after that time (Figure 2B). A similar pattern was observed in abundance of MYOD mRNA such that it increased initially, at $2 \mathrm{~h}$ post-induction to differentiate, and decreased after that time (Figure 2C). Myogenin was not expressed by any of the cultures at any time point assessed. These data demonstrate that the steroidal hormones found in anabolic implants increase abundance of MYF5 at 4 and $8 \mathrm{~h}$, respectively, post-induction to differentiate. Furthermore, mRNA abundance of MYF5 and MYOD is altered in BSCs temporally.

\subsection{The Effects of Steroidal Hormones on Abundance of $m R N A$ Involved in the Polyamine Biosynthesis Pathway}

The mRNA abundance of genes involved in the polyamine biosynthesis pathway $(O D C$ and $A M D 1)$ was affected $(p<0.05)$ by treatment with the hormones found in anabolic implants (Figure 3). Additionally, a steroidal hormone*time interaction $(p=0.003)$ was observed for $A M D 1$ (Figure 3A). Eight hours post-induction to differentiate, $A M D 1$ abundance was increased $(p=0.006)$ when BSCs were treated with TBA (Figure 3A). Estradiol decreased $(p=0.02)$ abundance of ODC $12 \mathrm{~h}$ post-induction to differentiate (Figure 3B) compared to control cultures. There was also an effect $(p<0.05)$ of time on abundance of both $A M D 1$ and $O D C$ (Figure 3). Abundance of $A M D 1$ increased $(p<0.05)$ at 4 and $8 \mathrm{~h}$ post-induction to differentiate, then decreased after that time. Similarly, abundance of $O D C$ increased from 2 to $8 \mathrm{~h}$ post-induction to differentiate, then decreased after that time point. These data demonstrate that the steroidal hormones found in anabolic implants impact abundance of the two main rate limiting enzymes in the polyamine biosynthesis pathway. Furthermore, abundance of these enzymes changes over time following induction of differentiation.

\subsection{The Effects of Polyamine Precursors on Abundance of mRNA Related to Satellite Cell Differentiation}

No effect $(p>0.05)$ of the interaction between polyamine precursor*time was observed in mRNA abundance of MYF5 or MYOD, however there was a polyamine precursor*treatment effect ( $p=0.04$ ) observed for PAX7 mRNA (Figure 4). Relative mRNA abundance of PAX7 was affected $(p<0.001)$ by treatment when a polyamine precursor when analyzed as a repeated measure. However, neither polyamine precursor affected $(p>0.05)$ abundance of PAX7 compared to the control cultures at any of the analyzed time points (Figure 4A). Additionally, mRNA of MYF5 was affected $(p=0.05)$ by treatment with polyamine precursors (Figure 4B). Compared to control cultures, MET increased $(p=0.05)$ abundance of MYF5 $4 \mathrm{~h}$ post-induction to differentiate (Figure 4B). No effect $(p>0.05)$ of treatment with polyamine precursor was observed in abundance of MYOD. However, MET increased ( $p=0.008) M Y O D$ abundance $24 \mathrm{~h}$ post-induction to differentiate compared to control cultures (Figure 4C). Additionally, ORN increased mRNA abundance of MYOD $8 \mathrm{~h}$ $(p=0.05)$ and $24 \mathrm{~h}(p=0.007)$ post-induction to differentiate compared to control cultures (Figure 4C). Myogenin was not expressed by any of the cultures at any time point assessed. Abundance of both PAX7 and MYOD was affected $(p<0.05)$ by time such that expression of each gene was increased $(p<0.05) 2 \mathrm{~h}$ post-induction to differentiate and then decreased after that time point. The data presented here demonstrate that polyamine precursors generally increase abundance of genes involved in BSC differentiation.

\subsection{The Effects of Polyamine Precursors on Abundance of mRNA Involved in the Polyamine Biosynthesis Pathway}

No effect of polyamine precursor $(p>0.05)$ or polyamine precursor*time interaction $(p>0.05)$ was observed relative to AMD1 mRNA abundance (Figure 5A). However, an effect of polyamine precursor $(p=0.03)$, time $(p<0.001)$ and their interaction $(p=0.008)$ was observed on abundance of $O D C$ mRNA (Figure $5 \mathrm{~B}$ ). Twenty-four h post-induction to differentiate, ORN increased $(p=0.04)$ abundance of ODC when compared to control cul- 
tures (Figure 5B). Additionally, abundance of $A M D 1$ and $O D C$ were both affected $(p<0.05)$ by time (Figure 5). Abundance of $A M D 1$ increased $4 \mathrm{~h}$ after induction of differentiation and then decreased after that time, whereas abundance of $O D C$ increased $2 \mathrm{~h}$ after differentiation was induced and decreased after that time (Figure 5). Taken together, these data demonstrate that treatment with polyamine precursors effects abundance of ODC but has no effect on $A M D 1$ temporally.

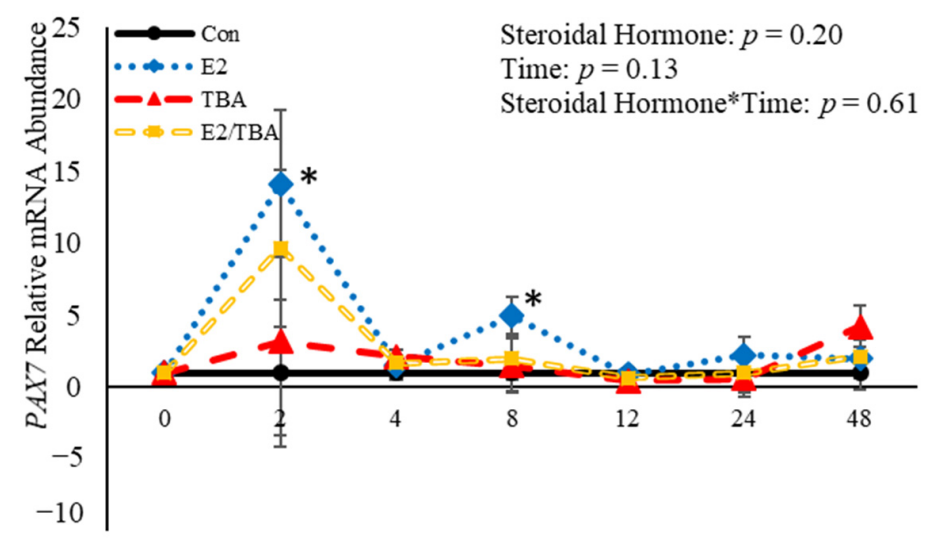

(A)

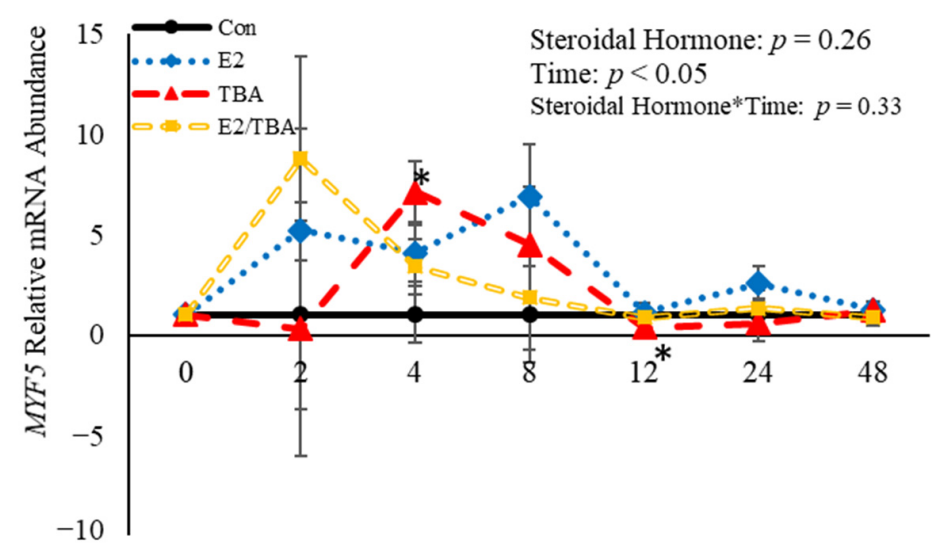

(B)

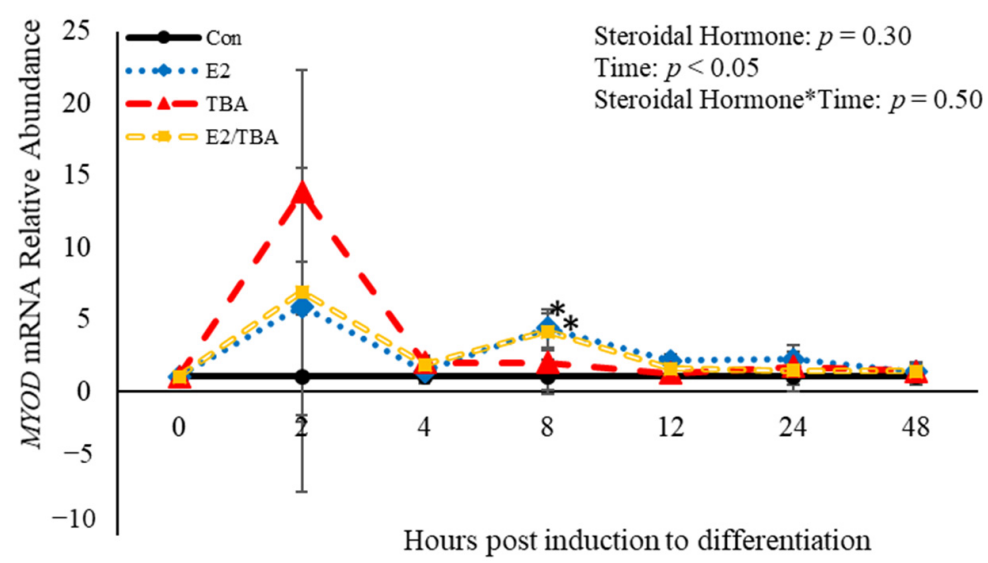

(C)

Figure 2. Relative mRNA abundance of paired box transcription factor 7 (PAX7; (A), myogenic factor 5 (MYF5; (B), and myogenic differentiation factor 1 (MYOD; (C) from primary bovine satellite cells 
cultures following treatment with $10 \mathrm{nM}$ trenbolone acetate (TBA), $10 \mathrm{nM}$ estradiol (E2), or $10 \mathrm{nM}$ E2 and $10 \mathrm{nM}$ TBA (E2/TBA). Cultures were grown to 80\% confluency and treated with DMEM/3\% horse serum and $10 \mathrm{nM}$ TBA, $10 \mathrm{nM} \mathrm{E2,} \mathrm{or} 10 \mathrm{nM}$ E2/TBA. Abundance was measured 0, 2, 4, $8,12,24$ and $48 \mathrm{~h}$ after treatment, as described in the Materials and Methods. The main effects of steroidal hormone, time and steroidal hormone*time in mRNA abundance were analyzed as repeated-measures. Data represent relative mRNA abundance, normalized against $18 \mathrm{~S}$ abundance and are presented as LS mean \pm SEM from six separate replicates utilizing BSCs isolated BSCs isolated from at least three different animals. Differences $(p<0.05)$ between steroidal hormones found in anabolic implants and the control cultures are indicated by $a{ }^{*}$ at that particular time point.

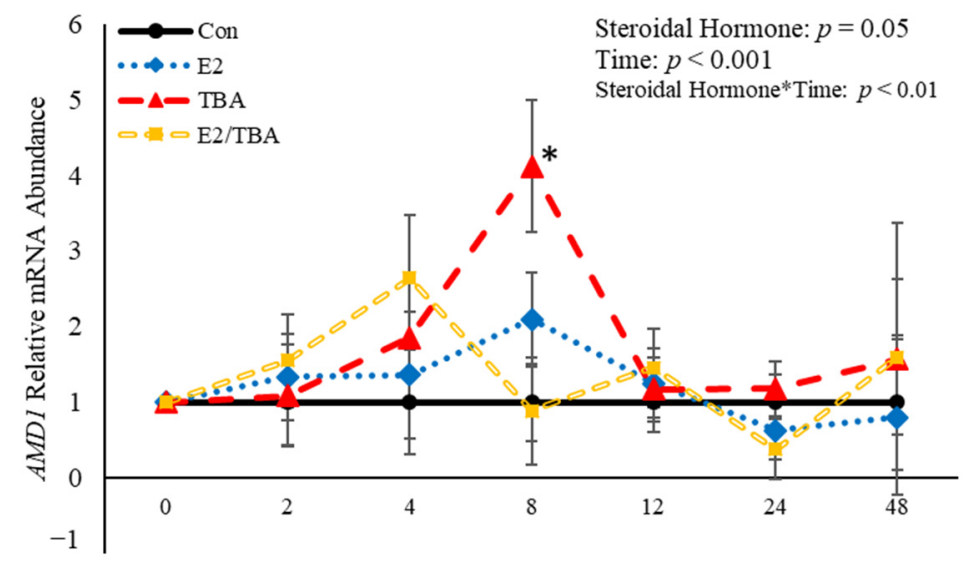

(A)

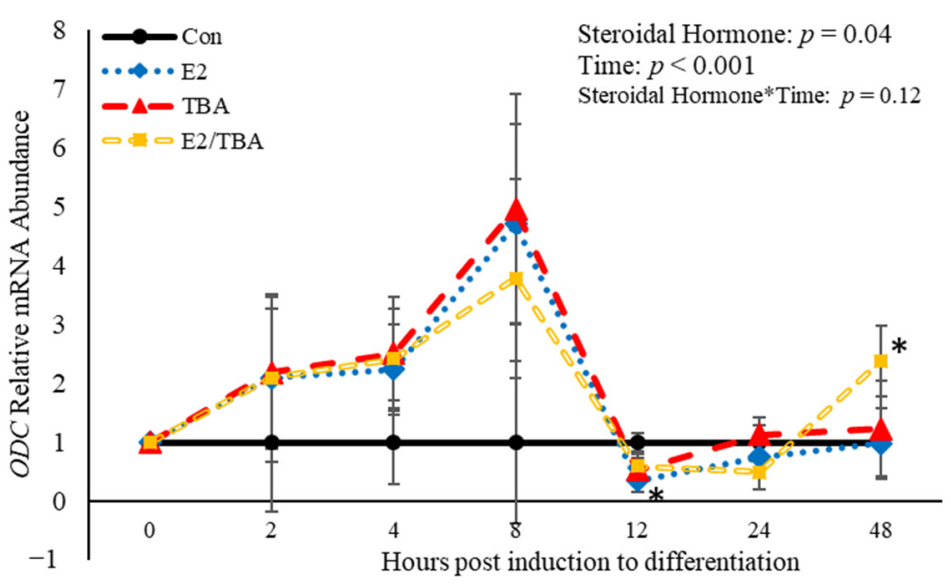

(B)

Figure 3. Relative mRNA abundance of S-adenosylmethionine decarboxylase (AMD1; (A) and ornithine decarboxylase (ODC; (B) from primary bovine satellite cells cultures following treatment with $10 \mathrm{nM}$ trenbolone acetate (TBA), $10 \mathrm{nM}$ estradiol (E2), or $10 \mathrm{nM}$ E2 and $10 \mathrm{nM}$ TBA (E2/TBA). Cultures were grown to $80 \%$ confluency and treated with DMEM/3\% horse serum and $10 \mathrm{nM}$ TBA, $10 \mathrm{nM}$ E2, or $10 \mathrm{nM}$ E2/TBA. Abundance was measured 0, 2, 4, 8, 12, 24 and $48 \mathrm{~h}$ after treatment, as described in the Materials and Methods. The main effects of steroidal hormone, time and steroidal hormone *time in mRNA abundance were analyzed as repeated-measures. Data represent relative mRNA abundance normalized against $18 \mathrm{~S}$ abundance and are presented as LS mean \pm SEM from six separate replicates utilizing BSCs isolated BSCs isolated from at least three different animals. Differences $(p<0.05)$ between steroidal hormones found in anabolic implants and the control cultures are indicated by a * at that particular time point. 


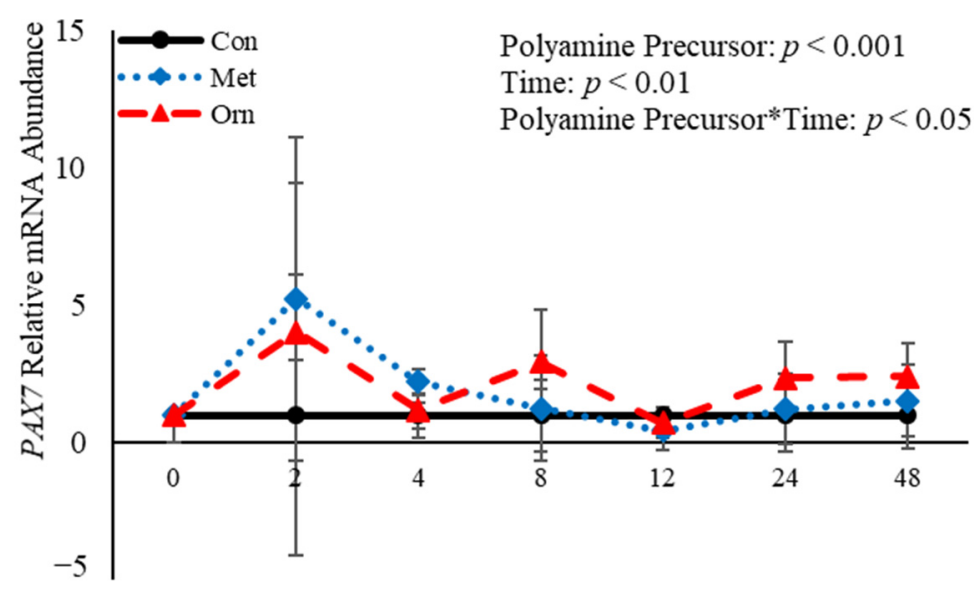

(A)

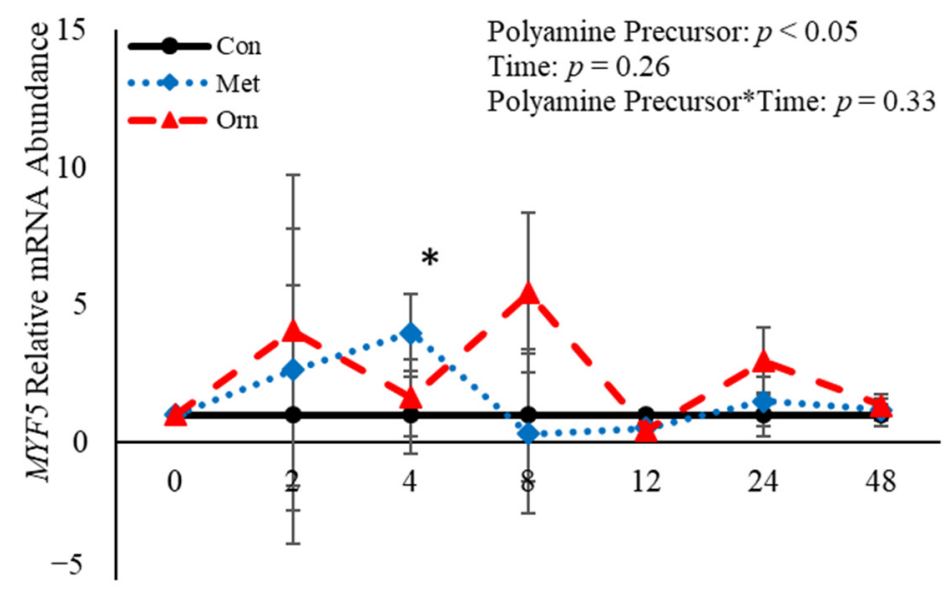

(B)

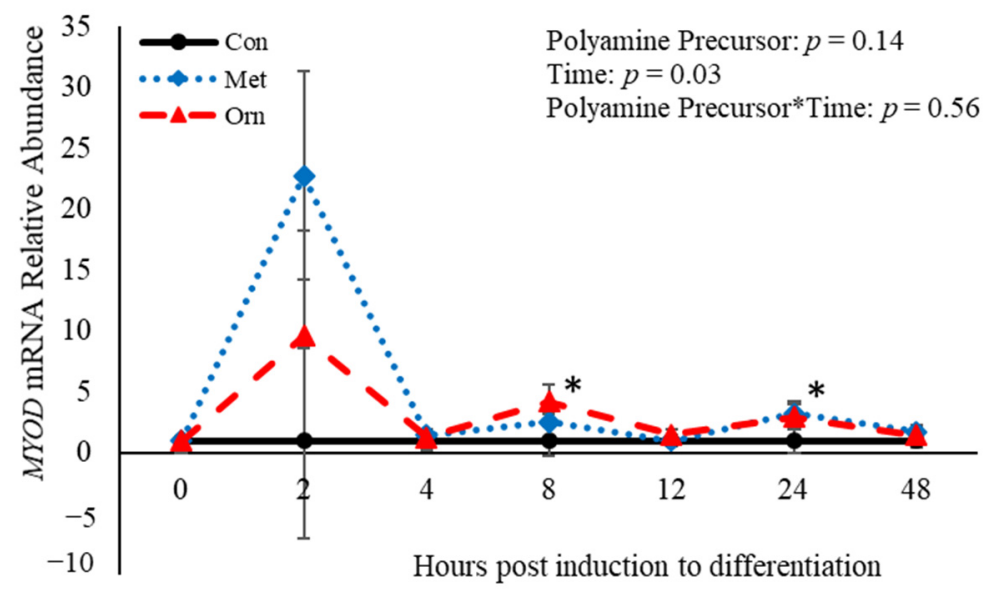

(C)

Figure 4. Relative mRNA abundance of paired box transcription factor 7 (PAX7; (A), myogenic factor 5 (MYF5; (B), and myogenic differentiation factor 1 (MYOD; (C) from primary bovine satellite cells cultures following treatment with $10 \mathrm{mM}$ methionine (MET) or $8 \mathrm{mM}$ ornithine (ORN). Cultures were grown to $80 \%$ confluency and treated with DMEM/3\% horse serum and $10 \mathrm{mM}$ MET or $8 \mathrm{mM}$ ORN. Abundance was measured 0,2, 4, 8, 12, 24 and $48 \mathrm{~h}$ after treatment, as described in the Materials and Methods. The main effects of polyamine precursor, time and polyamine precursor*time in mRNA 
abundance were analyzed as repeated-measures. Data represent relative mRNA abundance normalized against $18 \mathrm{~S}$ abundance and are presented as LS mean \pm SEM from six separate replicates utilizing BSCs isolated BSCs isolated from at least three different animals. Differences $(p<0.05)$ between polyamine precursors and the control cultures are indicated by $\mathrm{a}$ * at that particular time point.

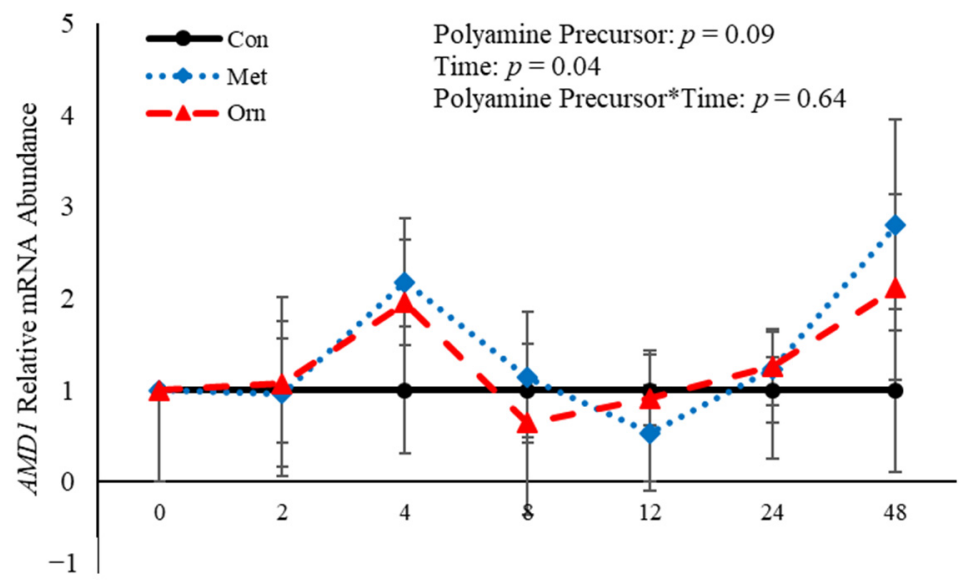

(A)

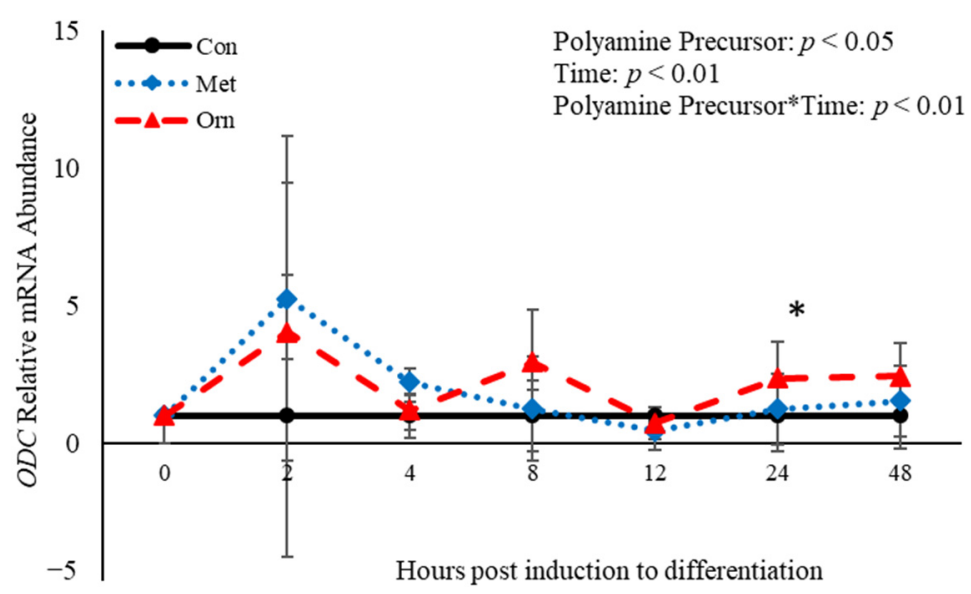

(B)

Figure 5. Relative mRNA abundance of S-adenosylmethionine decarboxylase (AMD1; (A) and ornithine decarboxylase $(O D C ;(\mathbf{B})$ from primary bovine satellite cells cultures following treatment with $10 \mathrm{mM}$ methionine (MET) or $8 \mathrm{mM}$ ornithine (ORN). Cultures were grown to $80 \%$ confluency and treated with DMEM/3\% horse serum and $10 \mathrm{mM}$ MET or $8 \mathrm{mM}$ ORN. Abundance was measured $0,2,4,8,12,24$ and $48 \mathrm{~h}$ after treatment, as described in the Materials and Methods. The main effects of polyamine precursor, time and polyamine precursor*time in mRNA abundance were analyzed as repeated-measures. Data represent relative mRNA abundance normalized against $18 \mathrm{~S}$ abundance and are presented as LS mean \pm SEM from six separate replicates utilizing BSCs isolated BSCs isolated from at least three different animals. Differences $(p<0.05)$ between polyamine precursors and the control cultures are indicated by $\mathrm{a}^{*}$ at that particular time point.

\subsection{The Effects of Polyamines on Abundance of mRNA Related to Satellite Cell Differentiation}

No effects $(p>0.05)$ of the interaction between polyamine*time were observed relative to mRNA abundance of PAX7, MYF5, or MYOD (Figure 6). However, treatment with polyamines affected $(p=0.05)$ abundance of $P A X 7$ when analyzed as a repeated-measures (Figure 6A). Specifically, abundance of PAX7 was increased ( $p=0.02) 4 \mathrm{~h}$ post-induction to 
differentiate by SPD (Figure 6A), and $24 \mathrm{~h}(p=0.002)$ post-induction to differentiate by PUT (Figure 6A). Despite the increase in abundance by SPD and PUT, SPE decreased ( $p=0.04)$ abundance of $P A X 712 \mathrm{~h}$ post-induction to differentiate (Figure $6 \mathrm{~A}$ ) compared to control cultures. Although there was no effect $(p>0.05)$ of polyamine on abundance of MYF5 when analyzed as a repeated measure, SPE increased $(p=0.02)$ abundance of MYF5 $4 \mathrm{~h}$ postinduction to differentiate, but decreased $(p=0.05)$ abundance of MYF5 $12 \mathrm{~h}$ post-induction to differentiate when compared to control-treated cultures (Figure 6B). Similarly, there was no effect $(p>0.05)$ of polyamine treatment on abundance of MYOD when analyzed as a repeated-measures (Figure 6C). However, PUT increased ( $p=0.04$ ) abundance of $M Y O D$ $24 \mathrm{~h}$ post-induction to differentiate (Figure $6 \mathrm{C}$ ). Additionally, abundance of $P A X 7$, MYF5 and MYOD were each affected $(p<0.05)$ by time. Abundance of PAX7 increased $(p<0.05)$ $2 \mathrm{~h}$ post-induction to differentiate then decreased after that before increasing $(p<0.05)$ again $48 \mathrm{~h}$ post-induction to differentiate (Figure 6A). Myogenin was not expressed in any of the cultures at any time point assessed. Abundance of both MYF5 and MYOD mRNA increased $2 \mathrm{~h}$ post-induction to differentiate then decreased after that time (Figure $6 \mathrm{~B}, \mathrm{C}$ ). Overall, these data demonstrate that polyamines generally increase expression of genes involved in BSC differentiation in a temporal manner.

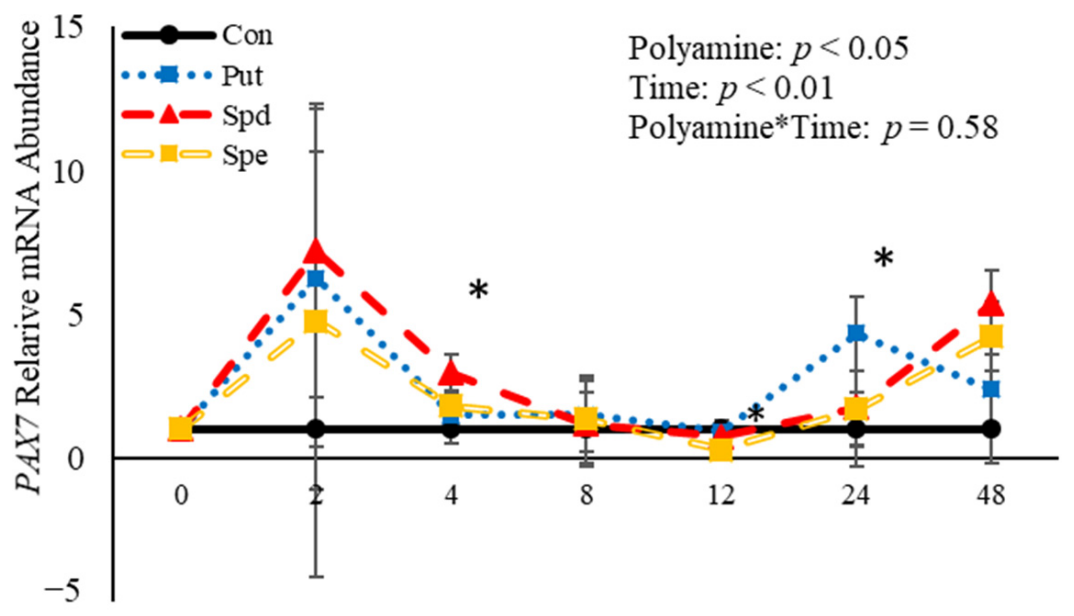

(A)

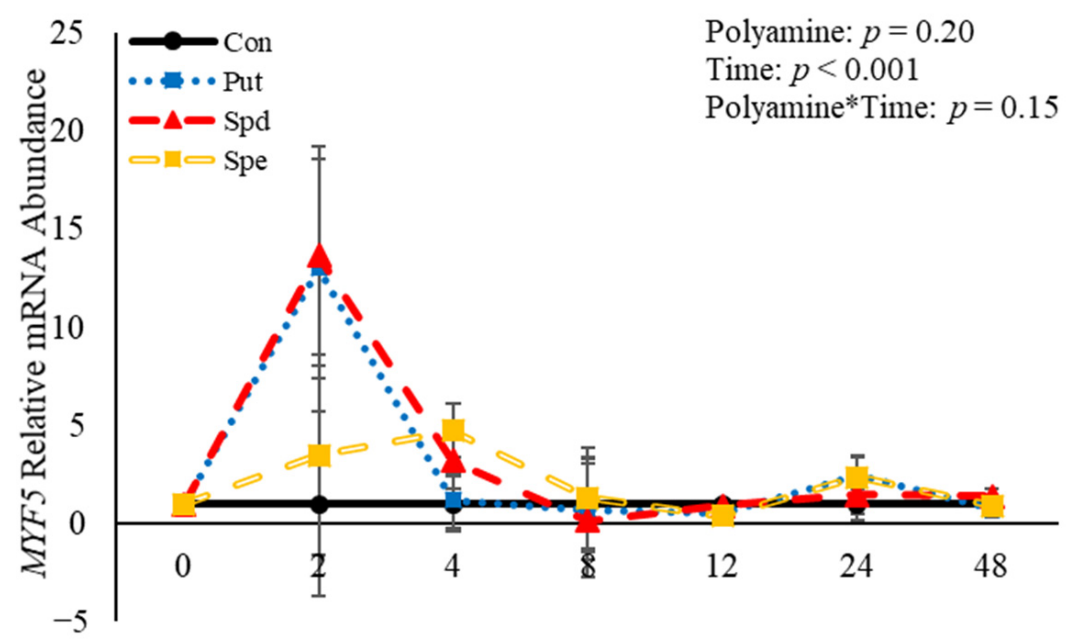

(B)

Figure 6. Cont. 


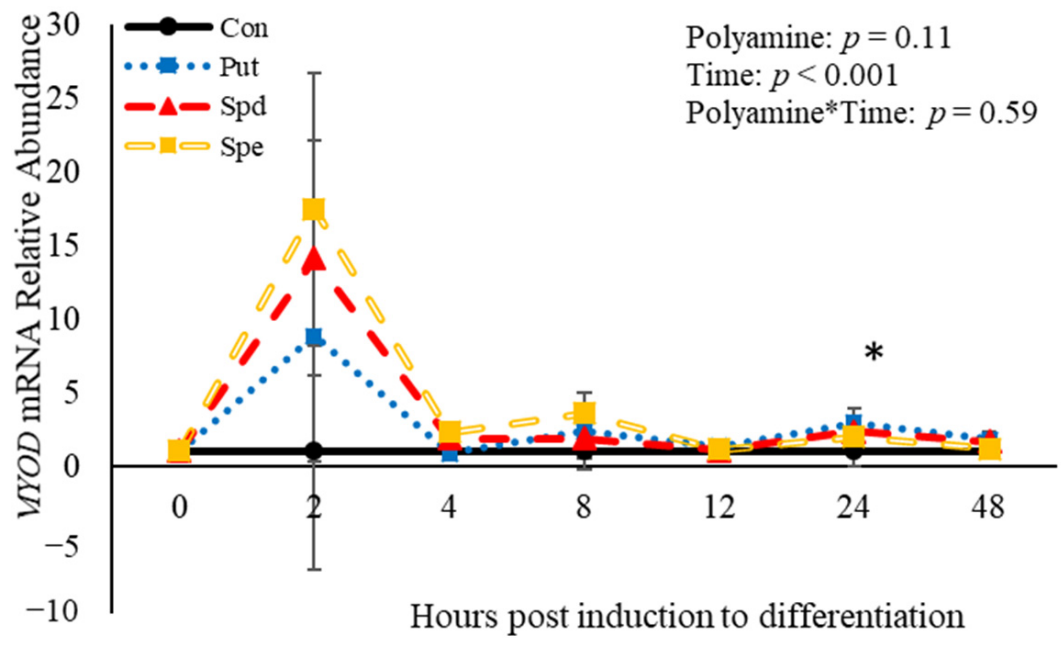

(C)

Figure 6. Relative mRNA abundance of paired box transcription factor 7 (PAX7; (A), myogenic factor 5 (MYF5; (B), and myogenic differentiation factor 1 (MYOD; (C) from primary bovine satellite cells cultures following treatment with $2 \mathrm{mM}$ putrescine (PUT), $1.5 \mathrm{mM}$ spermidine (SPD) or $0.5 \mathrm{mM}$ spermine (SPE). Cultures were grown to $80 \%$ confluency and treated with DMEM/3\% horse serum and $2 \mathrm{mM}$ PUT, $1.5 \mathrm{mM}$ SPD, or 0.5 mM SPE. Abundance was measured 0, 2, 4, 8, 12, 24 and $48 \mathrm{~h}$ after treatment, as described in the Materials and Methods. The main effects of polyamine, time and polyamine*time in mRNA abundance were analyzed as repeated-measures. Data represent relative mRNA abundance normalized against $18 \mathrm{~S}$ abundance and are presented as LS mean \pm SEM from six separate replicates utilizing BSCs isolated BSCs isolated from at least three different animals. Differences $(p<0.05)$ between polyamines and the control cultures are indicated by $\mathrm{a}^{*}$ at that particular time point.

3.6. The Effects of Polyamines on Abundance of $m R N A$ Involved in the Polyamine Biosynthesis Pathway

No polyamine*time interactions $(p>0.05)$ were observed relative to mRNA abundance of $A M D 1$ or $O D C$ (Figure 7$)$. However, there was an effect $(p=0.04)$ of polyamine treatment where PUT increased ( $p=0.02)$ abundance of AMD1 $2 \mathrm{~h}$ post-induction to differentiate (Figure 7A). Additionally, SPD increased $(p=0.02)$ abundance of AMD1 compared to control cultures $4 \mathrm{~h}$ post-treatment (Figure 7A). There was no effect $(p>0.05)$ of time on abundance of $A M D 1$ (Figure 7A). In contrast, there was an effect ( $p=0.008$ ) of time on abundance of ODC. However, there was no effect $(p>0.05)$ of polyamine treatment (Figure 7B). Abundance of $O D C$ increases $(p<0.05) 2 \mathrm{~h}$ post-induction to differentiate then decreased after that time before increasing $(p<0.05)$ again at $48 \mathrm{~h}$ (Figure $7 \mathrm{~B})$. The data presented here demonstrate that $O D C$ is not altered by polyamines, while both PUT and SPD alter mRNA abundance of $A M D 1$ in BSCs induced to differentiate. 


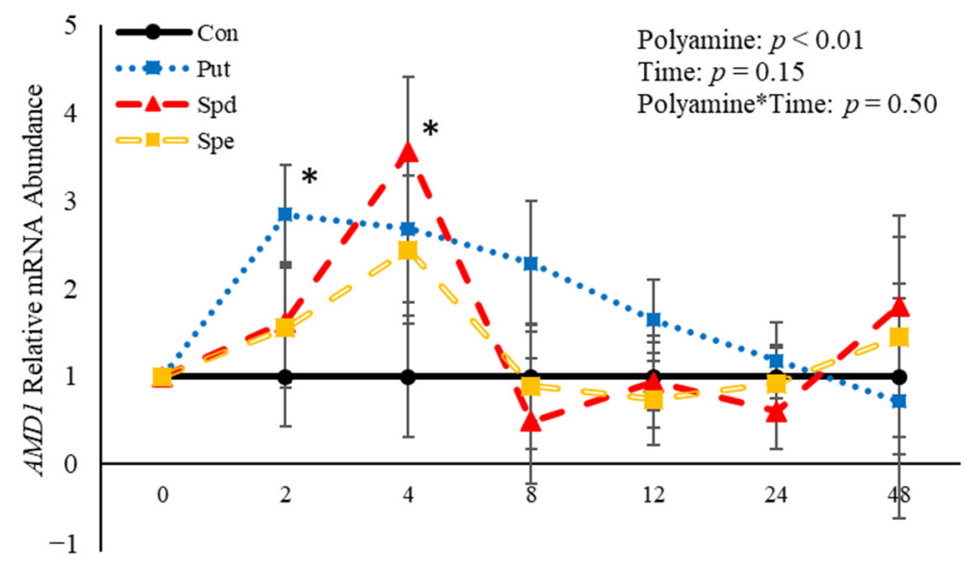

(A)

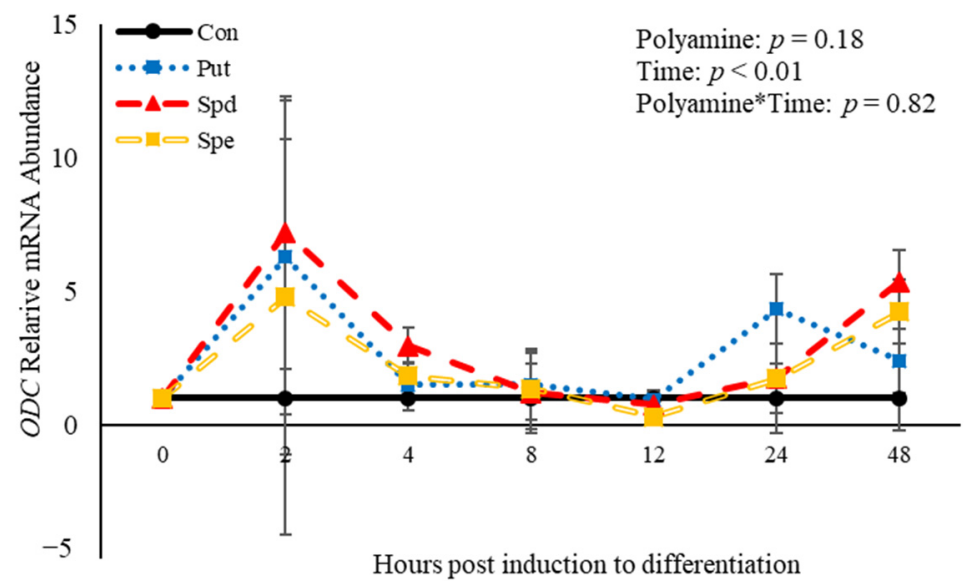

(B)

Figure 7. Relative mRNA abundance of S-adenosylmethionine decarboxylase (AMD1; A) and ornithine decarboxylase $(O D C$; B) from primary bovine satellite cells cultures following treatment with $2 \mathrm{mM}$ putrescine (PUT), $1.5 \mathrm{mM}$ spermidine (SPD) or $0.5 \mathrm{mM}$ spermine (SPE). Cultures were grown to $80 \%$ confluency and treated with DMEM/3\% horse serum and $2 \mathrm{mM}$ PUT, $1.5 \mathrm{mM}$ SPD, or $0.5 \mathrm{mM} \mathrm{SPE}$. Cultures were grown to $80 \%$ confluency and treated with DMEM/3\% horse serum and $10 \mathrm{nM}$ TBA, $10 \mathrm{nM}$ E2, or $10 \mathrm{nM} \mathrm{E2/TBA.} \mathrm{Abundance} \mathrm{was} \mathrm{measured} \mathrm{0,} \mathrm{2,} \mathrm{4,} \mathrm{8,} \mathrm{12,} 24$ and $48 \mathrm{~h}$ after treatment, as described in the Materials and Methods. The main effects of polyamine, time and polyamine*time in mRNA abundance were analyzed as repeated-measures. Data represent relative mRNA abundance normalized against $18 \mathrm{~S}$ abundance and are presented as LS mean \pm SEM from six separate replicates utilizing BSCs isolated BSCs isolated from at least three different animals. Differences $(p<0.05)$ between polyamines and the control cultures are indicated by $\mathrm{a}^{*}$ at that particular time point.

\section{Discussion}

Understanding mechanisms of skeletal muscle growth is imperative to be able to increase both economic and environmental sustainability of the beef industry. Anabolic implants are used in the U.S. to improve growth of beef cattle, which increases the environmental and economic sustainability of the beef industry $[3,7,12,41]$, but their mechanisms of operation are unknown. Testosterone and E2 have both been shown to influence the polyamine biosynthesis pathway $[23,24,42,43]$, with emerging research suggesting that TBA may interact with the polyamine biosynthesis pathway to increase growth [25]. Polyamines are amino acids derivatives necessary for normal cellular proliferation and differentiation $[27,32]$. In cattle, the relationship between polyamines and growth remains ill-defined. 
The concentrations used to treat satellite cells in this study were determined based on previous research examining physiological polyamine concentrations in bovine lymphocytes [27]. Emerging research demonstrates that in BSCs, polyamines enhance proliferation rates [25], although their effect on differentiating BSCs is currently unknown. Therefore, the purpose of this research was to investigate the effects of polyamines, polyamine precursors, and steroidal hormones on mRNA abundance of BSCs induced to differentiate, as satellite cells must be able to differentiate in order to fuse into myotubes or with existing fibers properly [44]. Furthermore, we aimed to determine the effects that each of these molecules has on the polyamine biosynthetic pathway.

In the present study, the effects of the steroidal hormones found in anabolic implants (E2 and /or TBA) on abundance of mRNA involved in the early stages of BSC differentiation (PAX7, MYF5, and MYOD) were investigated within the first $48 \mathrm{~h}$ of induction of differentiation. Investigating differentiation in the first $48 \mathrm{~h}$ of induction is important, as changes in myoblast differentiation have been reported to occur before $24 \mathrm{~h}$ [45]. A potential limitation of this study is that protein expression was not also investigated, as gene abundance can be influenced by the stability of the transcript and rate of transcription [46]. However, satellite cell activity may be evaluated using the mRNA abundance of myogenic regulatory factors [47], with measuring mRNA abundance to examine myogenic regulatory factors being routinely used by our lab group [25] and other lab groups [22,48] when studying satellite cells. Additionally, as this study is investigating the transition that occurs early on in BSCs when induced to differentiate, measuring mRNA abundance is the best option, as it is more sensitive to detect these changes and occurs before protein expression. The earliest changes that occur in differentiation are Pax7 decreasing, while abundance of Myf5 and $M y o D$ increases $[6,9,10]$. The increase in $M y o D$, is then eventually followed by an increase in myogenin, but this happens much later in differentiating satellite cells [45]. In human skeletal muscle myoblasts, changes in myogenin are not detected until $72 \mathrm{~h}$ postinduction to differentiate [45], in rat satellite cells, myogenin peaks $3 \mathrm{~d}$ after being induced to differentiate [49], and in BSCs, myogenin is barely detectable after $48 \mathrm{~h}$ in differentiation media [50]. Due to the fact that myogenin is barely detectable after $48 \mathrm{~h}$ in BSCs induced to differentiate, when mRNA abundance of myogenin was measured in this study it was too early for it be expressed as this study was looking at the mRNA tanscripts in the first $48 \mathrm{~h}$ of BSCs induced to differentiate. In the current study, when the BSCs were induced to differentiate, $P A X 7 \mathrm{mRNA}$ abundance increased $2 \mathrm{~h}$ post-induction, and then proceeded to decrease in abundance. One possible explanation for this is that satellite cells are a heterogeneous population, with a portion of cells remaining in reserve and proliferating, not differentiating [8]. Additionally, the compounds used in this study have been found to increase proliferation rates of BSCs [25], and therefore it would not be surprising if some of the cells remained in a proliferative phase initially when being induced to differentiation. Another possible explanation for the variation observed in this study at $2 \mathrm{~h}$ is that even though the cultures used in this study were pure, they were primary cells, as previously mentioned satellite cells are a heterogeneous population of cells [5]. Therefore, it quite possible that even though the cells were induced to differentiate, the BSCs could have been in different stages of the myogenic process. The results of the present study demonstrate that treatment of BSC cultures induced to differentiate with E2 and/or TBA did not impact mRNA abundance of $P A X 7, M Y F 5$ or MYOD at the time points measured when analyzed as repeated-measures. However, when contrasts were performed on each treatment relative to the control, cultures treated with E2/TBA increased abundance of MYOD $8 \mathrm{~h}$ post-induction of differentiation. Furthermore, MYOD abundance was increased by E2. Estradiol also increased abundance of $P A X 7$, while TBA did temporally enhance MYF5 abundance when compared to control cultures. Other research has demonstrated that testosterone accelerates differentiation in C2C12 myoblastoma [51], as well as pushing $\mathrm{C} 3 \mathrm{H}$ 10T1/2, pluripotent cells, towards a myogenic lineage [52]. Further, androgens may enhance cellular differentiation in $\mathrm{C} 2 \mathrm{C} 12$ cells through the androgen-androgen receptor signaling pathway leading to an increase in expression of myogenin, without altering 
$M y o D$ [33]. Additionally, when muscle derived stem cells are isolated from fetal calves at $180 \mathrm{~d}$ of gestation and treated with TBA, there is an increase in MYOD protein, which the authors postulated was mediated through the androgen receptor [53]. Previous research also found that BSCs treated with TBA or E2 had increased fusion indexes at 48 and $72 \mathrm{~h}$ post-differentiation when compared to control cultures [22]. However, PAX7 and MYOD mRNA abundance was not altered in these differentiated BSC cultures. Additionally, in porcine satellite cells treated with testosterone, differentiation has been shown to be decreased [54]. These previous studies contrast with the results of the present study in that TBA, a testosterone analog, did not impact abundance of MYOD, MYF5 or PAX7 at the time points measured. However, the present study also found when BSCs are induced to differentiate and are treated with E2 and E2/TBA, there is an increase in mRNA abundance of these genes at specific time points suggesting that E2 may also play a role in differentiation of bovine satellite cells. This corresponds to previous research demonstrating that E2 and TBA increase fusion indexes of BSCs at 48 and $72 \mathrm{~h}$ post-differentiation [22]. However, in mice satellite cells, E2 has been shown to inhibit myogenesis by repressing the fusion of myoblasts into myotubes [55]. These findings suggest that steroidal hormones may impact abundance of mRNA involved in BSC differentiation at certain time points. One explanation for the lack of results presented in the present study is that it is not uncommon for delayed differentiation to occur in satellite cells, when proliferation and muscle mass are increased [54,56-58]. However, additional research is needed to further understand how treatment of BSCs with the steroidal hormones found in anabolic implants alters BSC differentiation.

The present study also assessed whether TBA, E2 or TBA/E2 affects mRNA abundance of $A M D 1$ or $O D C$. The present study found that TBA, E2 and TBA/E2 increase abundance of $A M D 1$ and $O D C$ temporally in differentiating BSCs. Previous research has shown that a single injection of E2 increases $O d c$ within $24 \mathrm{~h}$ in rats [23], while in proliferating breast cancer cells, E2 increased abundance of $O d c$ and polyamine concentrations [24]. Mice that have been castrated have a decreased abundance of $O d c$, yet when these castrated mice are treated with testosterone, $O d c$ abundance increases [59]. In previous research conducted utilizing proliferating BSCs, TBA does not alter abundance of $A M D 1$ or $O D C$ [25]. Increased expression of ODC is thought to promote myoblast proliferation, but delay myogenic differentiation [60]. In proliferating BSCs isolated BSCs isolated from finished steers, ORN and MET have both been found to increase abundance of $O D C$ [25]. In this research, ODC abundance was decreased by ORN $24 \mathrm{~h}$ post-induction to differentiate. This correlates with the increased abundance of $M y o D 24 \mathrm{~h}$ post-treatment in ORN-treated cultures, suggesting that the decrease in $O D C$ that has been observed in myogenic differentiation [60] occurs in differentiating BSCs.

Methionine and ORN were found to increase mRNA abundance of PAX7, MYF5, and MYOD temporally in differentiating BSCs. In vitro studies examining MET and ORN in mammalian cells are limited, with nearly none occurring in livestock species. The concentration of MET used in this study was chosen based off previous research conducted by our lab group determining the optimal concentration to increase BSC proliferation [25]. This is important in an ovine model, as growth of cultured satellite cells is extremely sensitive to the amount of MET in the medium [61]. A number of research trials have used in vivo studies to investigate MET supplementation. When MET is supplemented to Holstein feeder steers, it has been found that gain efficiency increases linearly with MET supplementation [62]. The varying degrees of MET supplementation impacting differentiation suggests that an optimal MET concentration needs to be determined at different stages of growth to optimize growth of beef. Methionine is known to be a limiting amino acid in beef [63]. Therefore, when looking at whole animal studies, it is difficult to determine whether changes in growth are attributed to satellite cell differentiation, protein synthesis, or effects on other systems within the body. Ornithine has been shown to assist with increasing protein synthesis in skeletal muscle of humans post-surgery [64]. Furthermore, MET and ORN can be utilized as an energy source when metabolized [65,66], 
which may alter energy balance within the cell resulting in altered differentiation. As such, more research needs to be performed to determine the mechanism through which MET and ORN may be altering differentiation of primary BSCs.

When polyamine precursors are decarboxylated, polyamines are produced [28]. Polyamines are orally active and can be derived from the diet, or endogenous production in the tissues through the polyamine biosynthesis pathway $[26,28]$. This research found that SPD increased PAX7 mRNA abundance $4 \mathrm{~h}$ post-treatment compared to controls. Spermine did decrease $P A X 7$ abundance $12 \mathrm{~h}$ post-treatment in the present study. Additionally, we found that $4 \mathrm{~h}$ post-treatment, TBA and SPE both increased MYF5 abundance, an important regulator of satellite cell differentiation [44].

Additionally, the present study examined the impact of polyamines on mRNA abundance of the rate limiting steps in the polyamine biosynthesis pathway. When differentiating BSCs are treated with the polyamines, PUT and SPD, abundance of AMD1 is increased. However, treatment with polyamines had no effect on $O D C$ abundance. Other research has found that when proliferating BSCs are treated with SPD or SPE, AMD1 abundance is increased [25], while abundance of $O D C$ is not altered [25]. Additional research needs to be completed to determine how the polyamines impact both growth of skeletal muscle and the polyamine biosynthetic pathway in beef animals.

The overall finding of this research suggests that steroidal hormones largely do not impact mRNA abundance in BSCs induced to differentiate, but polyamines and their precursors do increase abundance of genes related to BSC differentiation. Furthermore, steroidal hormones, polyamine, and polyamine precursors were each found to impact the polyamine biosynthetic pathway. Therefore, future work needs to investigate the interplay of these growth promotants and the polyamine biosynthesis pathway on cattle skeletal muscle as a whole, as it is difficult to ascertain whether increased growth comes from increased proliferation, differentiation, protein synthesis, other mechanisms or a combination of these factors.

Author Contributions: Conceptualization, G.K.M. and K.J.T.; data curation, C.C.R., L.L.O., L.A.M. and K.J.T.; formal analysis, C.C.R., L.L.O., L.A.M., B.P.G. and K.J.T.; funding acquisition, K.J.T.; investigation, C.C.R., L.A.M., G.K.M. and K.J.T.; methodology, G.K.M. and K.J.T.; project administration, K.J.T.; resources, G.K.M. and K.J.T.; software, K.J.T.; supervision, K.J.T.; validation, L.L.O.; visualization, K.J.T.; writing—original draft, C.C.R.; writing—review and editing, C.C.R., L.L.O., L.A.M., G.K.M. and K.J.T. All authors have read and agreed to the published version of the manuscript.

Funding: This work is funded by Hatch Capacity Grant Project no. UTA-01249 from the USDA National Institute of Food and Agriculture.

Institutional Review Board Statement: Bovine satellite cells were isolated from three different steers raised and harvested following procedures approved by the Institutional Animal Care and Use Committee (IACUC Protocol \# 10216) at Utah State University.

Data Availability Statement: The data presented in this study are available upon request from the corresponding author. The data are not publicly available due to restrictions in place by the funding agency.

Acknowledgments: The authors would like to thank Bryce Roholt, and the Utah State University Farm Crew for raising the animals, as well as Haden Davis and Bridgerland Technical College for their assistance with harvesting the animals.

Conflicts of Interest: The authors declare no conflict of interest.

\section{References}

1. Thornton, K.J. Triennial Growth Symposium: The Nutrition of Muscle Growth: Impacts of nutrition on the proliferation and differentiation of satellite cells in livestock species. J. Anim. Sci. 2019, 29, 2258-2269. [CrossRef] [PubMed]

2. England, E.; Scheffler, T.; Kasten, S.; Matarneh, S.; Gerrard, D. Exploring the unknowns involved in the transformation of muscle to meat. Meat Sci. 2013, 95, 837-843. [CrossRef]

3. Capper, J.L.; Hayes, D.J. The environmental and economic impact of removing growth-enhancing tech-nologies from US beef production. J. Anim. Sci. 2012, 90, 3527-3537. [CrossRef] 
4. Hawke, T.J.; Garry, D.J. Myogenic satellite cells: Physiology to molecular biology. J. Appl. Physiol. 2001, 91, 534-551. [CrossRef] [PubMed]

5. Li, J.; Gonzalez, J.M.; Walker, D.K.; Hersom, M.J.; Ealy, A.D.; Johnson, S.E. Evidence of heterogeneity within bovine satellite cells isolated from young and adult animals. J. Anim. Sci. 2011, 89, 1751-1757. [CrossRef] [PubMed]

6. Yablonka-Reuveni, Z. The skeletal muscle satellite cell: Still young and fascinating at 50. J. Histochem. Cytochem. 2011, 59, 1041-1059. [CrossRef]

7. Dayton, W.R.; White, M.E. Meat science and muscle biology symposium-Role of satellite cells in ana-bolic steroid-induced muscle growth in feedlot steers. J. Anim. Sci. 2014, 92, 30-38. [CrossRef]

8. Gonzalez, M.L.; I Busse, N.; Waits, C.M.; E Johnson, S. Satellite cells and their regulation in livestock. J. Anim. Sci. 2020, 98. [CrossRef]

9. Halevy, O.; Piestun, Y.; Allouh, M.Z.; Rosser, B.W.; Rinkevich, Y.; Reshef, R.; Rozenboim, I.; Wleklinski-Lee, M.; Yablonka-Reuveni, Z. Pattern of Pax7 expression during myogenesis in the posthatch chicken establishes a model for satellite cell differentiation and renewal. Dev. Dyn. 2004, 231, 489-502. [CrossRef] [PubMed]

10. Yablonka-Reuveni, Z.; Day, K.; Vine, A.; Shefer, G. Defining the transcriptional signature of skeletal muscle stem cells. J. Anim. Sci. 2008, 1, E207-E216. [CrossRef] [PubMed]

11. Duckett, S.K.; Owens, F.N.; Andrae, J.G. Effects of Implants on Performance and Carcass Traits of Feedlot Steers and Heifers; Research Report P; FAO: Roma, Italy, 1997.

12. Duckett, S.K.; Pratt, S.L. Meat science and muscle biology symposium-Anabolic implants and meat quality. J. Anim. Sci. 2014, 92, 3-9. [CrossRef]

13. APHIS. The Use of Growth-Promoting Implants in U.S. Feedlots; USDA-APHIS-VS-CEAH-NAHMS: Fort Collins, CO, USA, 2013.

14. Kamanga-Sollo, E.; Thornton, K.J.; White, M.E.; Dayton, W.R. Role of g protein-coupled estrogen recep-tor-1, matrix metalloproteinases 2 and 9, and heparin binding epidermal growth factor-like growth factor in estradiol-17beta-stimulated bovine satellite cell proliferation. Domest. Anim. Endocrinol. 2014, 49, 20-26. [CrossRef]

15. Thornton, K.J.; Kamanga-Sollo, E.; White, M.E.; Dayton, W.R. Active g protein-coupled receptors (gpcr), matrix metalloproteinases 2/9 (mmp2/9), heparin-binding epidermal growth factor (hbegf), epidermal growth factor receptor (egfr), erbb2, and insulin-like growth factor 1 receptor (igf-1r) are necessary for trenbolone acetate-induced alterations in protein turnover rate of fused bovine satellite cell cul-tures. J. Anim. Sci. 2016, 94, 2332-2343.

16. Thornton, K.J.; Kamange-Sollo, E.; White, M.E.; Dayton, W.R. Role of G protein-coupled receptors (GPCR), matrix metalloproteinases 2 and 9 (MMP2 and MMP9), heparin-binding epidermal growth factor-like growth factor (hbEGF), epidermal growth factor receptor (EGFR), erbB2, and insulin-like growth factor 1 receptor (IGF-1R) in trenbolone acetate-stimulated bovine satellite cell proliferation. J. Anim. Sci. 2015, 93, 4291-4301. [CrossRef]

17. Kamanga-Sollo, E.; Thornton, K.; White, M.; Dayton, W. Role of G protein-coupled estrogen receptor-1 in estradiol $17 \beta$-induced alterations in protein synthesis and protein degradation rates in fused bovine satellite cell cultures. Domest. Anim. Endocrinol. 2017, 58, 90-96. [CrossRef]

18. Kamanga-Sollo, E.; White, M.E.; Chung, K.Y.; Johnson, B.J.; Dayton, W.R. Potential role of g- pro-tein-coupled receptor 30 (gpr30) in estradiol-17beta-stimulated igf-i mrna expression in bovine satel-lite cell cultures. Domest. Anim. Endocrinol. 2008, 35, 254-262. [CrossRef]

19. Kamanga-Sollo, E.; White, M.E.; Hathaway, M.R.; Chung, K.Y.; Johnson, B.J.; Dayton, W.R. Roles of IGF-I and the estrogen, androgen and IGF-I receptors in estradiol-17beta- and trenbolone acetate-stimulated pro-liferation of cultured bovine satellite cells. Domest. Anim. Endocrinol. 2008, 35, 88-97. [CrossRef]

20. Kamanga-Sollo, E.; White, M.E.; Hathaway, M.R.; Weber, W.J.; Dayton, W.R. Effect of Estradiol-17beta on protein synthesis and degradation rates in fused bovine satellite cell cultures. Domest. Anim. Endo-Crinol. 2010, 39, 54-62. [CrossRef]

21. Kamanga-Sollo, E.; White, M.; Hathaway, M.; Weber, W.; Dayton, W. Effect of trenbolone acetate on protein synthesis and degradation rates in fused bovine satellite cell cultures. Domest. Anim. Endocrinol. 2011, 40, 60-66. [CrossRef] [PubMed]

22. Zhang, Z.; Zhao, L.D.; Johnson, S.E.; Rhoads, M.L.; Jiang, H.; Rhoads, R.P. Oxytocin is involved in steroid hormone-stimulated bovine satellite cell proliferation and differentiation in vitro. Domest. Anim. Endocrinol. 2019, 66, 1-13. [CrossRef] [PubMed]

23. Russell, D.H.; Taylor, R.L. Polyamine Synthesis and Accumulation in the Castrated Rat Uterus after Estradiol-17 $\beta$ Stimulation. Endocrinology 1971, 88, 1397-1403. [CrossRef]

24. Thomas, T. Estradiol control of ornithine decarboxylase mRNA, enzyme activity, and polyamine levels in MCF-7 breast cancer cells: Therapeutic implications. Breast Cancer Res. Treat. 1994, 29, 189-201. [CrossRef]

25. Reichhardt, C.; Ahmadpour, A.; Christensen, R.; Ineck, N.; Murdoch, G.; Thornton, K. Understanding the influence of trenbolone acetate and polyamines on proliferation of bovine satellite cells. Domest. Anim. Endocrinol. 2021, 74, 106479. [CrossRef]

26. Pegg, A.E.; McCann, P.P. Polyamine metabolism and function. Am. J. Physiol. Physiol. 1982, 243, C212-C221. [CrossRef]

27. Igarashi, K.; Kashiwagi, K. Polyamines: Mysterious Modulators of Cellular Functions. Biochem. Biophys. Res. Commun. 2000, 271, 559-564. [CrossRef]

28. Thomas, T.; Thomas, T.J. Polyamines in cell growth and cell death: Molecular mechanisms and thera-peutic applications. CMLS MLS 2001, 58, 244-258. [CrossRef] 
29. Murdoch, G.K.; Okine, E.K.; Christopherson, R.J. Chapter 5 Metabolic Modifiers in Animal Nutrition: Po-Tential Benefits and Risks. In Biology of Growing Animals; Mosenthin, R., Zentek, J., Żebrowska, T., Eds.; Elsevier: Amsterdam, The Netherlands, 2006; pp. 135-178.

30. Bardócz, S.; Duguid, T.J.; Brown, D.S.; Grant, G.; Pusztai, A.; White, A.; Ralph, A. The importance of dietary polyamines in cell regeneration and growth. Br. J. Nutr. 1995, 73, 819-828. [CrossRef]

31. Gouru, A.; Murdoch, G. PSVII-36 Examining the effect of a physiological dose of the polyamine; spermine, on myogenic regulatory transcription factor expression. J. Anim. Sci. 2019, 97, 359. [CrossRef]

32. Lee, N.K.L.; MacLean, H.E. Polyamines, androgens, and skeletal muscle hypertrophy. J. Cell. Physiol. 2011, 226, 1453-1460. [CrossRef]

33. Lee, D.K. Androgen receptor enhances myogenin expression and accelerates differentiation. Biochem. Biophys. Res. Commun. 2002, 294, 408-413. [CrossRef]

34. Frey, R.S.; Johnson, B.J.; Hathaway, M.R.; White, M.E.; Dayton, W.R. Growth factor responsiveness of prima-ry satellite cell cultures from steers implanted with trenbolone acetate and estradiol-17ß. Basic Appl. Myol. 1995, 5, 71-79.

35. Hathaway, M.R.; Hembree, J.R.; Pampusch, M.S.; Dayton, W.R. Effect of transforming growth factor beta-1 on ovine satellite cell proliferation and fusion. J. Cell Physiol. 1991, 146, 435-441. [CrossRef] [PubMed]

36. Chapalamadugu, K.C.; Robison, B.D.; Drew, R.E.; Powell, M.S.; Hill, R.A.; Amberg, J.J.; Rodnick, K.J.; Hardy, R.W.; Hill, M.L.; Murdoch, G.K. Dietary carbohydrate level affects transcription factor expression that regulates skeletal muscle myogenesis in rainbow trout. Comp. Biochem. Physiol. Part. B Biochem. Mol. Biol. 2009, 153, 66-72. [CrossRef] [PubMed]

37. Thornton, K.J.; Welch, C.M.; Davis, L.C.; Doumit, M.E.; Hill, R.A.; Murdoch, G.K. Bovine sire selection based on maintenance energy affects muscle fiber type and meat color of F1 progeny. J. Anim. Sci. 2012, 90, 1617-1627. [CrossRef] [PubMed]

38. Perez, R.; Tupac-Yupanqui, I.; Dunner, S. Evaluation of suitable reference genes for gene expression studies in bovine muscular tissue. BMC Mol. Biol. 2008, 9, 79. [CrossRef]

39. Green, A.; Wells, D.; Oback, B. Cattle Cloned from Increasingly Differentiated Muscle Cells. Biol. Reprod. 2007, 77, 395-406. [CrossRef]

40. Sabourin, L.A.; Girgis-Gabardo, A.; Seale, P.; Asakura, A.; Rudnicki, M.A. Reduced Differentiation Potential of Primary MyoD-/- Myogenic Cells Derived from Adult Skeletal Muscle. J. Cell Biol. 1999, 144, 631-643. [CrossRef]

41. Duckett, S.K.; Andrae, J.G. Implant strategies in an integrated beef production system. J. Anim. Sci. 2001, 79, E110-E117. [CrossRef]

42. Cepero, M.; Cubria, J.C.; Reguera, R.; Balana-Fouce, R.; Ordonez, C.; Ordonez, D. Plasma and Muscle Poly-amine Levels in Aerobically Exercised Rats Treated with Salbutamol. J. Pharm. 1998, 50, 1059-1064. [CrossRef]

43. Käpyaho, K.; Pösö, H.; Jänne, J. Role of propylamine transferases in hormone-induced stimulation of polyamine biosynthesis. Biochem. J. 1980, 192, 59-63. [CrossRef]

44. Le Grand, F.; Rudnicki, M.A. Skeletal muscle satellite cells and adult myogenesis. Curr. Opin. Cell Biol. 2007, 1, 628-633. [CrossRef]

45. Le Bihan, M.C.; Barrio-Hernandez, I.; Mortensen, T.P.; Henningsen, J.; Jensen, S.S.; Bigot, A.; Blagoev, B.; Butler-Browne, G.; Kratchmarova, I. Cellular proteome dynamics during differentiation of human primary myoblasts. J. Preoteom. Res. 2015, 7, 3348-3361. [CrossRef]

46. Greenbaum, D.; Jansen, R.; Gerstein, M. Analysis of mRNA expression and protein abundance data: An approach for the comparison of the enrichment of features in the cellular population of proteins and transcripts. Bioinformation 2002, 18, 585-596. [CrossRef]

47. Jeanplong, F.; Bass, J.J.; Smith, H.K.; Kirk, S.P.; Kambadur, R.; Sharma, M.; Oldham, J.M. Prolonged underfeeding of sheep increases myostatin and myogenic regulatory factor Myf-5 in skeletal muscle while IGF-I and myogenin are repressed. J. Endocrinol. 2003, 176, 425-437. [CrossRef] [PubMed]

48. Yates, D.T.; Clarke, D.S.; Macko, A.R.; Anderson, M.J.; Shelton, L.A.; Nearing, M.; Allen, R.E.; Rhoads, R.; Limesand, S.W. Myoblasts from intrauterine growth-restricted sheep fetuses exhibit intrinsic deficiencies in proliferation that contribute to smaller semitendinosus myofibres. J. Physiol. 2014, 592, 3113-3125. [CrossRef]

49. Reuveni, Z.Y.-; Rivera, A.J. Temporal expression of regulatory and structural muscle proteins during myogenesis of satellite cells on isolated adult rat fibers. Dev. Biol. 1994, 164, 588-603. [CrossRef]

50. Kook, S.-H.; Son, Y.-O.; Choi, K.-C.; Lee, H.-J.; Chung, W.-T.; Hwang, I.-H.; Lee, J.-C. Cyclic mechanical stress suppresses myogenic differentiation of adult bovine satellite cells through activation of extracellular signal-regulated kinase. Mol. Cell. Biochem. 2007, 309, 133-141. [CrossRef] [PubMed]

51. Diel, P.; Baadners, D.; Schlupmann, K.; Velders, M.; Schwarz, J.P. C2C12 myoblastoma cell differentiation and proliferation is stimulated by androgens and associated with a modulation of myostatin and Pax7 expression. J. Mol. Endocrinol. 2008, 40, 231-242. [CrossRef] [PubMed]

52. Singh, R.; Artaza, J.N.; Taylor, W.E.; Gonzalez-Cadavid, N.F.; Bhasin, S. Androgens stimulate myogenic differentiation and inhibit adipogenesis in $\mathrm{C} 3 \mathrm{H}$ 10T1/2 pluripotent cells through an androgen receptor-mediated pathway. Endocrinology 2003, 144, 5081-5088. [CrossRef] [PubMed]

53. Zhao, J.-X.; Hu, J.; Zhu, M.-J.; Du, M. Trenbolone enhances myogenic differentiation by enhancing $\beta$-catenin signaling in muscle-derived stem cells of cattle. Domest. Anim. Endocrinol. 2011, 40, 222-229. [CrossRef]

54. Doumit, M.E.; Cook, D.R.; Merkel, R.A. Testosterone up-regulates androgen receptors and decreases differentiation of porcine myogenic satellite cells in vitro. Endocrinology 1996, 137, 1385-1394. [CrossRef] [PubMed] 
55. Ogawa, M.; Yamaji, R.; Higashimura, Y.; Harada, N.; Ashida, H.; Nakano, Y.; Inui, H. 17ß-Estradiol Represses Myogenic Differentiation by Increasing Ubiquitin-specific Peptidase 19 through Estrogen Receptor $\alpha^{*}$. J. Biol. Chem. 2011, 286, 41455-41465. [CrossRef]

56. Picard, B.; Depreux, F.; Geay, Y. Muscle differentiation of normal and double-muscled bovine foetal myoblasts in primary culture. Basic Appl. Myol. 1998, 8, 197-203.

57. Quinn, L.S.; Ong, L.D.; Roeder, R.A. Paracrine control of myoblast proliferation and differentiation by fibroblasts. Dev. Biol. 1990, 140, 8-19. [CrossRef]

58. Dodson, M.V.; McFarland, D.C.; Grant, A.L.; Doumit, M.E.; Velleman, S.G. Extrinsic regulation of domestic animal-derived satellite cells. Domest. Anim. Endocrinol. 1996, 13, 107-126. [CrossRef]

59. Goldstone, A.; Koenig, H.; Lu, C. Testosterone-dependent sexual dimorphism of the mouse kidney is me-diated by polyamines. Biochem. Biophys. Res. Commun. 1982, 104, 165-172. [CrossRef]

60. Lee, N.K.L.; Skinner, J.P.J.; Zajac, J.D.; MacLean, H.E. Ornithine decarboxylase is upregulated by the androgen receptor in skeletal muscle and regulates myoblast proliferation. Am. J. Physiol. Metab. 2011, 301, E172-E179. [CrossRef] [PubMed]

61. Pan, Y.; Webb, K.E., Jr. Peptide-bound methionine as methionine sources for protein accretion and cell proliferation in primary cultures of ovine skeletal muscle. J. Nutr. 1998, 128, 251-256. [CrossRef]

62. Torrentera, N.; Carrasco, R.; Salinas-Chavira, J.; Plascencia, A.; Zinn, R.A. Influence of methionine supple-mentation of growing diets enriched with lysine on feedlot performance and characteristics of diges-tion in Holstein steer calves. Asian-Australas. J. Anim. Sci. 2017, 30, 42. [CrossRef]

63. Klemesrud, M.J.; Klopfenstein, T.J.; Lewis, A.J. Metabolizable methionine and lysine requirements of growing cattle. J. Anim. Sci. 2000, 78, 199-206. [CrossRef]

64. Wernerman, J.; Hammarqvist, F.; Von der Decken, A.; Vinnarts, E. Ornithine-alpha-ketoglutarate improves skeletal muscle protein synthesis as assessed by ribosome analysis and nitrogen use after surgery. Ann. Surg. 1987, 206, 674-678. [CrossRef] [PubMed]

65. Schroeder, G.; Awawdeh, M.; Gnad, D.; Titgemeyer, E.C. Effects of energy source on methionine utilization by growing steers. Kans. Agric. Exp. Stn. Res. Rep. 2005, 84, 1505-1511. [CrossRef]

66. Schneider, J.; Niermann, K.; Wendisch, V.F. Production of the amino acids l-glutamate, l-lysine, l-ornithine and l-arginine from arabinose by recombinant Corynebacterium glutamicum. J. Biotechnol. 2011, 154, 191-198. [CrossRef] [PubMed] 